\title{
E-Wom Terhadap Akun Beauty Vlogger @Kekeshabila Yang Dilakukan Milenial di Kota Samarinda
}

\author{
Muhamad Nano Sucipto'; Trisda Derama ${ }^{2}$ \\ Universitas Mulawarman, Samarinda, Indonesia \\ e-mail: mnanosucipto@gmail.com, trisdaderama16@gmail.com
}

\begin{abstract}
Abstrak. Berkembangnya teknologi menjadikan kegiatan komunikasi antar manusia turut berubah. Media sosial diciptakan sebagai cara baru untuk saling berbagi informasi hanya dengan sekejap mata. Perkembangan tersebut juga memberi dampak pada berbagai bidang salah satunya bidang kecantikan, dimana sekarang dunia kecantikan dianggap sebagai hal penting bagi rata-rata perempuan. Kemudian, informasi tentang dunia kecantikan dibagikan melalui media sosial. Oleh karena itu, tujuan dari studi ini dilakukan guna mengetahui dan menjelaskan seberapa jauh kalangan milenial di Kota Samarinda saling berbagi informasi dari salah satu akun beauty vlogger @kekeshabila dengan menggunakan E-WoM. Dalam studi ini menggunakan pendekatan jenis penelitian kualitatif deskriptif. Teknik analisis data dilakukan melalui tiga tahapan, yaitu: mereduksi data, menyajikan data, dan menarik kesimpulan. Data dikumpulkan melalui dua cara, pertama adalah wawancara terhadap followers akun @kekeshabila dan kedua observasi terhadap akun @kekeshabila. Hasil dari penelitian ini menunjukkan bahwa followers akun @kekeshabila adalah pengguna aktif media sosial khususnya Instagram dan cukup aktif berbagi informasi menggunakan E-WoM. Serta konten pada akun @kekeshabila informatif dan kreatif sehingga followers tertarik untuk melihatnya.
\end{abstract}

Kata Kunci: Beauty Vlogger; E-Wom; Instagram; Generasi Milenial

Abstract. The development of technology makes communication among people also change. Social media was created as a new way to share information very quickly. These development also impacted various area, one of them is beauty, which is now it considered as an important thing for women. Then, information about beauty was shared through social media. Therefore, this research was conducted with the purpose of knowing and explaining how far the millenials in Samarinda City sharing information from beauty vlogger's account @kekeshabila by using E-WoM. The type of the research that used in this research was descriptive qualitative. Data analysis techniques was using three steps : reducing data, displaying data, and concluding/verification. The data was collected in two ways, first was interviewing the followers of @kekeshabila and second was observing@kekeshabila account. The results of this research shows that followers of @kekeshabila account are active social media users, especially Instagram and quite active in sharing information by using E-WoM. And, the contents on @kekeshabila account are informative and creative, so the followers are interested to seeing it.

Keywords: Beauty Vlogger; E-Wom; Instagram; Millenial Generation 


\section{A. PENDAHULUAN}

Manusia diciptakan oleh tuhan pada dasarnya termasuk akal pikiran serta budi dengan maksud supaya manusia dapat membedakan hal yang baik dan hal buruk serta berinteraksi satusama lain. Dan pada hakikatnya manusia sebagai mahluk tuhan memiliki kodrat yang saling membutuhkan, dan hidup saling tolong menolong dalam kelomopok. Oleh karena itu selama hidupnya mannusia akan selalu melaksanakan kegiatan interaksi dan berkomunikasi satu sama lain dalam kehidupannya sehari - hari. Seiring kemajuan zaman kegiatan interaksi dan komunikasi antar manusia semakin berkembang juga (Inah, 2013). Kemajuan teknologi yang canggih telah merubah proses komunikasi manusia. Oleh sebab itu, manusia harus pula berkembang dan berubah mengikuti arus kemajuan teknologi sehingga mampu bertahan dan berinteraksi dan berkomunikasi antar manusia. Kemajuan teknologi telah banyak membantu dan memberikan kemudahan dalam setiap informasi, karena didalam proses berbagi informasi satu sama lain hanya memakan waktu yang sangat singkat. Sebagai contoh kemunculan berbagai media sosial, sebagai alat komunikasi dan interaksi dalam bertuka informasi dalam waktu yang singkat (Sulistyowati et al., n.d.).

Perkembangan teknologi telah memberikan dampak yang signifikan dalam setiap bidang kehidupan manusia dewasa ini (Viviana \& Candraningrum, 2019). Termasuk didalamnya bidang kecantikan yang sangat maju dan berkembang akibat dampak dari teknologi. Sebelum era teknologi kita mengenal Makeup hanya merupakan kebutuhan skunder. tetapi pada zaman sekarang Makeup telah menjelmah menjadi suatu keharusan atau kebutuhan utama bagi kaum hawa. Makeup telah memunculkan sebuah nilai estetika dan telah menjadi trend bagi masyarakat umumnya jhususnya kaum hawa. Selain makeup, skincare juga telah menjadi perhatian utama bagi masyarakat dalam menujang penampilan dan mempercantik diri. Dari sanalah awal mula terciptanya kelompok - kelompok komunitas kecantikan yang biasa disebut secara luas dengan istilah beauty vlogger. "Beauty vlogger adalah orang-orang expert atau berkeahlian dalam bidang kecantikan, seperti makeup dan skincare kemudian memberi tips dan trik serta tutorial, dan hal-hal lainnya yang berkaitan dengan bidang kecantikan". Mereka telah membagikan berbagai informasi dan tips mengenai kecantikan di berbagai media social dalam bentuk video dan foto. Sebagai seorang beauty vlogger tidaklah muda dalam menjalankan profesinya, mereka dituntut untuk memiliki kepribadian yang khas dalam keseharian dan berperilaku serta harus memiliki keatifitas tinggi agar dapat bersaing serta menyesuaikan dengan apa yang audiens butuhkan (Pelayanan et al., 2019). Instagram merupakan suatu platform media sosial yang juga akan diteliti pada kesempatan kali ini.

Instagram merupakan bentuk media sosial yang berbasis fotografi telah diciptakan pada tahun 2010 silam oleh Kevin Systrom dan rekannya Mike Krieger (Aza, 2018). Sejak awal kemunculannya hingga sekarang, telah terjadi banyak kemajuan dan inovasi pada Instagram. Berbagai hal dapat di post ke dalam media sosail ini, anatara lain : Mengupload foto dan video, dapat saling berbalas komentar serta likes, tersedia juga filter-filter digital yang mampu mempercantik tampilan foto dan video, pengguna juga dapat menggunakan direct message dengan pengguna lainnya, dan sebagainya. Dari sebuah laman website start up yaitu laman napoleoncat.com, yang berupa sebuah pemasaran media sosial yang berkedudukan di Polandia, tercatat secara statistik bahwa jumlah dari pengguna Instagram yang ada di Indonesia sebanyak 65.780 .000 (data terakhir April 2020). Dimana jumlah tersebut adalah $24,1 \%$ dari jumlah populasi keseluruhan. Dapat dilihat dari data berikut, jumlah mayoritas pengguna Instagram adalah perempuan dengan total $51,1 \%$, sedangkan laki-laki sekitar 48,9\%. Rentang umur dengan persenan terbanyak adalah umur antara 18 
tahun - 24 tahun dengan bagian 38\% (Cat, 2020). Data-data tersebut sangat mendukung untuk penelitian yang akan dilakukan penulis kali ini karena berkaitan dengan beauty

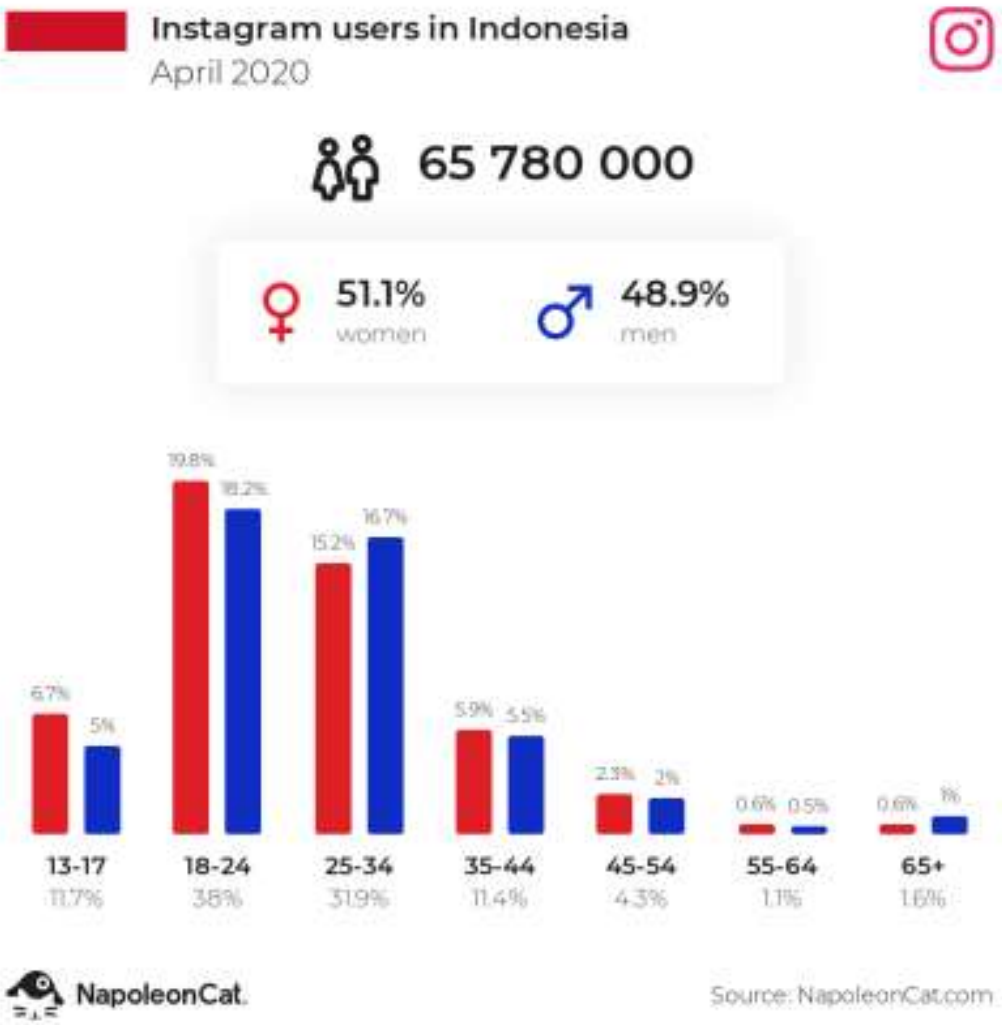

vlogger dan kalangan milenial.

\section{Gambar 1. Angka Pengguna Instagram di Indonesia}

Dari berbagai pemaparan diatas sehingga maka studi ini khusu meneliti dan menganalisa mengenai E-WoM terhadap sebuah akun beauty vlogger di Kota Samarinda yaitu @kekeshabila. Akun @kekeshabila adalah sebuah akun pribadi milik Keke Shabila, seorang influencer atau beauty vlogger yang aktif di Kota Samarinda. Dimana akun @kekeshabila ini telah mempunyai followers sebanyak 269.000 dengan postingan sebanyak 774 postingan di Instagramnya (per tanggal 1 Mei 2020). Selain akun tersebut, ada pula beberapa beauty vlogger lain di Kota Samarinda seperti @nadianraulya, @tasyamaswan, dan @ puteripw.

Tabel 1. Perbandingan Beberapa Akun Beauty Vlogger

\begin{tabular}{|l|l|l|l|l|}
\hline Akun & @kekeshabila & $\begin{array}{l}\text { @nadianrau } \\
\text { lya }\end{array}$ & $\begin{array}{l}\text { @tasyamas } \\
\text { wan }\end{array}$ & @puteripw \\
\hline $\begin{array}{l}\text { Jumlah } \\
\text { Pengikut }\end{array}$ & 269 ribu & 518 ribu & 8,1 ribu & 6,2 ribu \\
\hline $\begin{array}{l}\text { Postingan } \\
\text { Pertama }\end{array}$ & 27 Juli 2016 & $\begin{array}{l}19 \\
\text { Desember }\end{array}$ & $\begin{array}{l}11 \\
\text { September } \\
2016\end{array}$ & 17 Mei 2014 \\
& & 2015 & \\
\hline
\end{tabular}


Sumber : Hasil Observasi Penulis, 2020

Dari data - data pada tabel 1 di atas, dapat dirumuskan masalah dalam studi ini adalah sebagai berikut : "Bagaimana E-WoM Terhadap Akun Beauty Vlogger @kekeshabila yang Dilakukan Oleh Kalangan Milenial di Kota Samarinda"? sedangkan tujuan dari studi ini adalah dalam upaya mengetahui dan menjelaskan seberapa jauh kalangan milenial di Kota Samarinda berbagi informasi dari akun beauty vlogger @kekeshabila dengan menggunakan E-WoM.

\section{B. KAJIAN LITERATUR}

\section{A. Electronic Word of Mouth (E-WoM)}

E-WoM merupakan sebuah cara komunikasi dari mulut ke mulut yang dilakukan pada internet atau media sosail. Electronic word of mouth (E-WoM) suatu bentuk pengembangan dari WoM (Word of Mouth) tradisional di zaman digital ini, WoM tradisional dilakukan secara langsung dari satu individu ke individu lain, sedangkan E-WoM dilakukan dengan menggunakan media internet (HABIBAH, 2018).

"Word of Mouth adalah cara berbagi pendapat dan pemikiran mengenai berbagai barang dan layanan yang ditawarkan oleh pasar, pertukaran pendapat terjadi dengan lingkungan sekitar seperti keluarga, tetangga, dan sebagainya yang merupakan sumber yang dapat dipercaya. Sedangkan di dalam Electronic Word of Mouth (E-WoM) informasi yang didapatkan belum tentu terpercaya karena berasal dari sumber yang tidak dikenal, seperti sesama pengguna internet dan media sosial tertentu".

Berikut beberapa dimensi Electronic Word of Mouth (E-WoM) menurut Goyette et al (2020) antara lain:

1. Intensity, "Intensity (intensitas) dalam E-WoM merupakan banyaknya pendapat yang ditulis oleh konsumen dalam sebuah situs jejaring sosial". Dengan indikator sebagai berikut :
a. Seringnya mengakses suatu informasi dari situs jejaring sosial
b. Seringnya interaksi sesama pengguna situs jejaring sosial
c. Banyaknya komentar (kritik/saran) yang ditulis oleh pengguna situs jejaring sosial

2. Valence of Opinion "Valence of Opinion adalah pendapat dari pengguna baik positif ataupun negatif mengenai produk, jasa, brand, atau perusahaan". Dengan indikator sebagai berikut:
a. Rekomendasi dari sesama pengguna situs jejaring sosial
b. Komentar positif dari pengguna situs jejaring sosial
c. Komentar negatif dari pengguna situs jejaring sosial

3. Content "Content adalah informasi yang disediakan situs jejaring sosial berkaitan dengan produk dan jasa". Dengan indikatornya, sebagai berikut:
a. Informasi mengenai harga produk
b. Informasi variasi produk
c. Informasi kualitas produk
d. Informasi keamanan situs jejaring sosial
e. Informasi kemudahan transaksi

\section{B. Generasi Milenial}

"Generasi milenial sedang tren dibicarakan. Istilah generasi milenial diciptakan oleh dua pakar sejarah dan penulis Amerika, William Strauss dan Neil Howe. Generasi milenial juga dikenal sebagai generasi $Y$ yang disebut generation me atau echo boomers. Generasi ini digolongkan berdasarkan tahun awal dan akhir. Generasi $Y$ tergolong bagi mereka yang kelahiran tahun 1980-1990 atau pada awal 2000" (Kominfo, n.d.). 
“Generasi milenial berbeda dengan generasi sebelumnya, terutama sangat berbeda dalam hal yang berkaitan dengan teknologi. Di era generasi milenial perkembangan teknologi sudah sangat canggih, yang mana teknologi menjadikan para generasi milenial bergantung pada media sosial sebagai tempat bertukar informasi. Pada jaman sekarang, masyarakat lebih memilih media sosial platform dan sumber berita utama yang dapat diandalkan".

\section{Instagram}

Instagram adalah sebuah bentuk media sosial yang memungkinkan penggunanya untuk mengabil foto atau video kemuadian menshare secara online. Instagram merupakan media sosial yang diciptakan oleh Kevin Systrom dan Mike pada Oktober 2010. Pada Instagram pengguna dapat membagikan berbagai bentuk foto atau video yang merupakan kegiatan sehari-hari atau hanya untuk mencari informasi dengan melihat-lihat postingan pengguna lainnya (Putri, 2018).

Terdapat berbagai fitur pada Instagram berupa Instagram stories yaitu tempat bagi pengguna untuk menampilkn foto atau video yang dapat menarik perhatian dan serta menginspirasi dan terhubung dengan banyak pengguna lain yang sangat bermanfaat dalam pemasaran produk atau bisnis lainnya. Instagram stories juga termasuk dalam "discoverable" yang dapat membebaskan pengguna dalam melihat postingan orang lain meskipun tidak mengikutinya, fitur tersebut dapat dimanfaatkan dalam menciptakan viewers aktif pada unggahan-unggahan selanjutnya (Aprilia, 2016).

Instagram stories juga dapat menjadi alat bisnis guna proses produk branding. Instagram stories berguna dalam upaya terhubung dengan banyak viewers dalam proses pencapaian target, hal ini karena fitur tersebbut muncul dibagian atas yang memenuhi layar pengguna. Instagram stories juga mempermudahkan pengguna dalam berkomunikasi dan membagikan moment, foto dan video dengan sesama pengguna lainnya.

\section{Beauty Vlogger}

Beauty vlogger adalah sebuah profesi baru yang terciptakan melalui perkembangan kemajuan teknologi yang semakin canggih pada era media sosial yang fokusnya pada bidang kecantikan (beauty). Konten - konten berupa video yang dibuat oleh beauty vlogger merupakan hal-hal yang berkaitan dengan kecantikan (beauty), seperti makeup tutorial, tips dan trik, dan sebagainya yang menginspirasi kaum hawa (Mariezka et al., 2018).

Beauty vlogger merupakan profesi yang mendapat respon positif dari industri kecantikan. Tidak sedikit brand kecantikan yang mempercayakan kekuatan branding melaui jasa beauty vlogger guna menginspirasi da mempengaruhi viewers nya. Penjelasan produk secara rinci kepada target pasar oleh Beauty vlogger dapat mempengaruhi banyak audiens melalui video tutorial makeup, tips kecantikan trik berdandan atau bagaimana cara menggunakan suatu produk dengan benar. Dengan adanya beauty vlogger yang mengiklankan atau menawarkan suatu brand, maka brand menjadi lebih efektif untuk menyampaikan pesan dari produk tersebut kepada konsumen.

Brand - Brand ternama merasa sangat terbantu dengan kehadiran beauty vlogger saat ini, mereka dapat memberikan informasi yang jelas dengan cara yang menyenangkan dan persuasif. Audiens merasa lebih tertarik dan treinsirasi melalui tayangan iklan-iklan di jejaring sosial yang dilakukan oleh beauty vlogger lebih menarik dibanding di tempat lainnya. 


\section{METODOLOGI PENELITIAN}

Penelitian ini menggunakan pendekatan kualitatif deskriptif adalah jenis penelitian yang akan penulis lakukan kali ini. Menurut Denzin dan Lincoln (2009), kualitatif deskriptif merupakan metode penelitian dimana peneliti akan mencoba untuk menjelaskan serta memaparkan sebuah kegiatan atau objek yang diteliti, dimana hal tersebut akan berkaitan dengan pengkajian fenomena secara lebih rinci serta membedakannya dari fenomena yang lain.

Yang menjadi subjek penelitian dalam studi ini adalah "followers aktif akun beauty vlogger @kekeshabila yang merupakan kalangan milenial dan juga pemilik akun @kekeshabila yaitu Keke Shabila". Dengan menggunakan media sosial Instagram sebagai objek yang diteliti. Sedangkan cara dalam mengumpulkan informasi dilakukan dengan cara melakukan wawancara singkat kepada beberapa followers aktif dari akun @kekeshabila serta melakukan pengamatan kepada akun @kekeshabila, guna untuk mendapatkan yang valid.

Sedangkan yang menjadi tempat dan waktu penelitian yang dilakukan bertempat pada sosial media Instagram akun @kekeshabila. Pengamatan dilakukan dari tanggal 1 Mei 2020 hingga 7 Mei 2020 dalam kurun waktu 7 hari. Sedangkan untuk prosesi wawancara kepada followers akun @kekeshabila dilakukan dalam kurun waktu 2 hari, hari pertama adalah tanggal 4 Mei 2020 dan hari kedua adalah tanggal 5 Mei 2020.

Untuk menganalisis data, penulis menggunakan pendapat Sugiyono yaitu teknik analisis data dengan model Miles dan Huberman yang melalui tiga tahap. Tahap tersebut antara lain mereduksi data (data reduction), kemudian menyajikan data (data display), dan menarik simpulan (verification) (Prof. Dr. Sugiyono, 2015).

\section{HASIL DAN PEMBAHASAN}

Berikut merupakan poin-poin yang ditemukan oleh penulis, yaitu:

1. Followers Akun @Kekeshabila Berbagi Informasi Menggunakan E-WoM

Proses pertukaran informasi melalui media internet atau media sosial antar sesama pengguna internet disebut Electronic word of mouth. Penelitian ini adalah mengamai EWoM yang dilakukan oleh pengguna Instagram. Dan hasil dari wawancara yang penulis lakukan, menunjukkan bahwa ternyata para followers dari akun @kekeshabila sudah cukup aktif melakukan E-WoM, dengan cara mereka saling bertukar informasi terkait dunia kecantikan yang dibagikan oleh akun @kekeshabila. Mereka saling bertukar informasi atau sharing content dari akun @kekeshabila tidak hanya melalui fitur direct message Instagram, tetapi juga sharing content melalui media sosial lain seperti Whatsapp, Line, bahkan aplikasi Tiktok. Karena hal itulah akun @kekeshabila lebih dikenal oleh khalayak luas bahkan sampai ke luar Pulau Kalimantan. Hasil dari wawancara yang penulis lakukan juga menunjukkan bahwa terdapat beberapa followers yang belum melakukan E-WoM".

\section{Followers Akun @Kekeshabila Adalah Pengguna Instagram yang Aktif}

Berdasarkan hasil "wawancara kepada sepuluh narasumber yang merupakan followers akun @kekeshabila guna melengkapi data-data penelitian. Kriteria dari narasumber yang dipilih oleh penulis yaitu : 1) merupakan followers aktif dari akun @kekeshabila dan aktif memberikan like serta komentar di akun @kekeshabila, 2) followers adalah seseorang yang berdomisili di Kota Samarinda, 3) followers adalah generasi milenial yang memahami seluk beluk video dan foto konten dibagikan oleh akun @kekeshabila 
sebagai beauty vlogger. Setelah proses wawancara, didapatkan informasi bahwa narasumber adalah pengguna aktif Instagram, meski tidak setiap saat melakukan kegiatan pada akun mereka di Instagram.

3. Konten Yang Dibagikan Di Akun @Kekeshabila Merupakan Konten Informatif dan Kreatif

Konten pada akun @Kekeshabila berisi informasi dari situs jejaring sosial yang berhubungan dengan produk dan jasa. Pada penelitian ini, konten yang penulis bahas adalah foto dan video dari akun @kekeshabila sebagai beauty vlogger. Dari hasil wawancara yang dilakukan oleh penulis, didapatkan informasi bahwa rata-rata narasumber memberi jawaban bahwa konten foto dan video yang dibagikan akun @kekeshabila cukup informatif bagi mereka, dimana akun tersebut memberikan review terhadap brand makeup dan skincare yang sesuai dengan ekspektasi mereka dan followers lainnya.

4. Akun @kekeshabila juga memberikan berbagai macam tutorial, seperti tutorial makeup, skincare, bahkan tutorial hijab kepada followersnya. Narasumber juga menyatakan bahwa akun @kekeshabila cukup menginspirasi dan kreatif, selain itu juga konten foto dan video yang dibagikan oleh akun @kekeshabila telah diedit sedemikian rupa agar terlihat menarik. Penggunaan efek nya pun tidak berlebihan sehingga hasil foto dan videonya tetap terlihat asli dan alami.

5. Followers Akun @Kekeshabila Merasa Tertarik dengan Konten-Konten yang Diberikan

Konten-konten yang terdapat pada akun @kekeshabila tidak selalu membahas seputar kecantikan saja, namun terdapat konten lain juga. Seperti hasil wawancara yang dilakukan oleh penulis, didapatkan narasumber senang dengan konten cara menabung kekinian ala Keke Shabila. Selain itu, narasumber juga senang dengan review-review makanan atau produk lainnya yang ada di Kota Samarinda yang dilakukan oleh Keke Shabila.

Akun @kekeshabila juga sering membagikan kegiatan sehari-harinya. Membagikan foto-foto bersama keluarga, foto makeup tanpa di endorse, dan lain sebagainya. Dan juga akun @kekeshabila sering membagikan video kreatif nya dari Tiktok yang menghibur followersnya. Maka dari itu, followers merasa tertarik dengan konten yang dibagikan akun @kekeshabila karena tidak terlalu monoton.

6. Pemilik Akun @Kekeshabila, yaitu Keke Shabila Sering Berinteraksi dengan Followers

Seiring meningkatnya ketenaran dari akun @kekeshabila, sang pemilik akun, yaitu Keke Shabila juga berusaha untuk lebih dekat dengan para followersnya. Dari hasil wawancara yang dilakukan oleh penulis, narasumber menyatakan bahwa Keke Shabila merupakan orang yang ramah-tamah, baik, dan murah senyum dalam dunia nyata maupun dunia maya, seperti Instagram.

Keke Shabila selalu berusaha membangun hubungan dengan followersnya, yaitu menggunakan fitur question box yang disediakan oleh Instagram, dimana Keke Shabila akan menjawab beberapa pertanyaan yang diajukan oleh followersnya. Selain itu, Keke Shabila juga sering membalas komentar-komentar dari followers yang ada di postingan foto atau videonya. Dan juga terkadang Keke Shabila mengadakan giveaway di saat- 
saat tertentu untuk para followersnya. Begitulah cara dari akun @kekeshabila dalam membangun hubungan dengan followersnya. Hal tersebut pula yang membuat followers tetap setia mengikuti akun @kekeshabila dan merekomendasikan akun @kekeshabila kepada teman-temannya.

\section{Tabel 2. Hasil Wawancara Followers Akun @kekeshabila}

\begin{tabular}{|c|c|c|}
\hline No. & Nama Informan & Analisis \\
\hline 1. & @maulidhiya & $\begin{array}{l}\text { Sudah mengikuti akun @kekeshabila selama setahun terakhir. } \\
\text { Yang disukai oleh Maulidhiya dari akun @kekeshabila adalah hasil } \\
\text { makeup Keke yang menarik dan juga lucu serta lengkapnya } \\
\text { informasi dari review produk nya. }\end{array}$ \\
\hline 2. & @arinisyhdh & $\begin{array}{l}\text { Sudah mengikuti akun @kekeshabila selama kurang lebih } 4 \text { tahun } \\
\text { dengan alasan terkuat menyukai konten cara menabung kekinian } \\
\text { ala Keke Shabila dan makeup serta konten foto dan video yang } \\
\text { dibagikan sangat bagus dan rapi. }\end{array}$ \\
\hline 3. & @ahadia_ & $\begin{array}{l}\text { Sudah mengikuti akun @kekeshabila selama setahun terakhir, } \\
\text { karena melihat Keke Shabila sebagai beauty vlogger serta } \\
\text { menginspirasi untuk ber makeup. }\end{array}$ \\
\hline 4. & @ademelati_ & $\begin{array}{l}\text { Sudah mengikuti akun @kekeshabila selama kurang lebih } 4 \text { tahun. } \\
\text { Hal yang disukai dari Keke Shabila adalah orang yang ramah } \\
\text { walaupun sudah dikenal banyak orang dan juga mengetahui bahwa } \\
\text { informasi yang dibagikan Keke Shabila terkait review nya pasti } \\
\text { terpercaya. }\end{array}$ \\
\hline 5. & @frisqikha & $\begin{array}{l}\text { Sudah mengikuti akun @kekeshabila selama kurang lebih } 5 \text { tahun, } \\
\text { karena informasi yang dibagikan oleh akun @kekeshabila sangat } \\
\text { informatif dan kreatif. }\end{array}$ \\
\hline 6. & @rn_novii & $\begin{array}{l}\text { Sudah mengikuti akun @kekeshabila selama kurang lebih } 2 \text { tahun. } \\
\text { Menurut Novi, konten yang dibagikan sangat menarik dan juga } \\
\text { konten yang dibagikan cukup bermanfaat bagi followers. }\end{array}$ \\
\hline 7. & @melisamei29 & $\begin{array}{l}\text { Mengikuti akun @kekeshabila karena merasa menarik melihat } \\
\text { konten foto yang dibagikan setelah itu menginspirasi untuk makeup. } \\
\text { Menurut Melisa, akun @kekeshabila membantu dia yang awalnya } \\
\text { tidak bisa makeup menjadi bisa makeup, karena apa yang } \\
\text { dibagikan oleh Keke Shabila memberi tahukan makeup yang } \\
\text { mudah didapatkan. }\end{array}$ \\
\hline 8. & @syafinapspa & $\begin{array}{l}\text { Sudah mengikuti akun @kekeshabila selama kurang lebih setahun } \\
\text { terakhir. Syafina sangat menyukai look makeup Keke dan } \\
\text { menganggap Keke sangat fashionable. }\end{array}$ \\
\hline 9. & @_nurrz & $\begin{array}{l}\text { Sudah mengikuti akun @kekeshabila selama kurang lebih } 2 \text { tahun. } \\
\text { Menurut Nur, cara ber makeup yang dilakukan Keke Shabila cukup } \\
\text { unik. }\end{array}$ \\
\hline
\end{tabular}


10. @maulidaannisa_ Sudah mengikuti akun @kekeshabila selama kurang lebih 5 tahun. Menurut Maulida, konten yang dibagikan sangat informatif dan menghibur.

Sumber: Hasil Wawancara Penulis (2020)

Selain melakukan wawancara, penulis juga melakukan pengamatan penggunaan Instagram akun @kekeshabila guna mendapatkan data dalam periode 7 hari, yaitu tanggal 1 Mei 2020 sampai dengan tanggal 7 Mei 2020. Dalam periode 7 hari tersebut, akun @kekeshabila menggunggah 2 buah foto, 5 buah video, dan juga instastory. Unggahan foto, video, dan instastory merupakan unggahan bukan endorse, yang mana akun @kekeshabila hanya menggunggah foto dan video ber makeup yang digunakan dan sesuai keinginannya.

Akun @kekeshabila juga memiliki hashtag khas sebagai branding akun, yaitu \#kekemakeupan sehingga ketika followers mengklik hashtag tersebut, akan muncul konten foto dan video yang dibagikan oleh akun @kekeshabila. Dan juga akun @kekeshabila mencantumkan link akun Youtube nya yang bernama Keke Shabila. Sama halnya dengan Instagram, di akun Youtube nya Keke Shabila juga membahas seputar dunia kecantikan namun dalam durasi video yang lebih panjang. Selain menjadi beauty vlogger dan youtuber, Keke Shabila juga kerap diundang dalam acara-acara bertema dunia kecantikan secara langsung maupun daring. Hal ini dikarenakan followers yang senang dan berminat melihat professionalisme seorang Keke Shabila yang handal di bidang kecantikan.

\section{E. KESIMPULAN}

Pada era media social dewasa ini kehadiran beauty vlogger dirasakan sangat amat penting bagi Sebagian besar kaum hawa, guna bertukar informasi yang penting seputar dunia kecantikan antara lain trend makeup, skincare, dan info kecantikan lainnya. Kaum hawa merasa sangat terbantu melalui informasi yang dibagikan oleh beauty vlogger guna mendapatkan informasi kecantikan yang berguna dalam memeprcantik dan menunjang penampilan Sebagian masyarakat.banyaknya Informasi yang didapat beragam dari sumber yang beragam pul melalui kegiatan E-Wom yang dilakukan oleh followers pada fiturlikes, stories, direct message dan komentar via Instagram, Whatsapp, Line, bahkan aplikasi TikTok. Hal ini dilakukan melalui dukungan jaringan internet. Sebagai seorang beauty vlogger, juga bertugas untuk membangun brand disamping mempengaruhi dan mengajak followers atau audiens melalui share informasi via konten foto dan video seputar kecantikan. Berkomunikasi dan berinteraksi dengan para audiens atau followersnya agar terjalin bubungan yang loyal antara followers dengan pembuat konten. Konten yang dibuat pun dinilai berdasarkan seberapa informatif dan kreatifnya foto dan video yang dibagikan. Sehingga followers merasa yakin dengan ucapan atau review dan tutorial dari beauty vlogger tersebut. 


\section{DAFTAR PUSTAKA}

Aprilia, N. (2016). INSTAGRAM SEBAGAI AJANG EKSISTENSI DIRI Studi Fenomenologi Mengenai Pengguna Instagram Sebagai Ajang Eksistensi Diri Pada Mahasiswa IImu Komunikasi Fisip Unpas [Universitas Pasundan]. http://repository.unpas.ac.id/12619/

Aza, M. (2018). Selain Mark, Siapa Sih Penemu Media Sosial yang Sering Kamu Gunakan? IDN Times. https://www.idntimes.com/life/inspiration/muhajirin/penemumedia-sosial-c1c2-1/2

Cat, N. (2020). Instagram users in Indonesia April 2020. Napoleon Cat. https://napoleoncat.com/stats/instagram-users-in-indonesia/2020/04

HABIBAH, I. N. (2018). PENGARUH ELECTRONIC WORD OF MOUTH (E-WOM) YANG DILAKUKAN OLEH BEAUTY INFLUENCER TERHADAP MINAT BELI BRAND MAKE UP WARDAH (Study Pada Subscribers YouTube Channel Tasya Farasya). 6(3), 4-5. https://libraryeproceeding.telkomuniversity.ac.id/index.php/management/article/view/11 088

Inah, E. N. (2013). Peranan Komunikasi dalam Pendidikan. Jurnal Al-Ta'dib, 6(1). https://media.neliti.com/media/publications/235708-peranan-komunikasi-dalampendidikan-66310d01.pdf

Kominfo. (n.d.). Mengenal Generasi Millennial. Kominfo. Retrieved April 30, 2020, from https://www.kominfo.go.id/content/detail/8566/mengenal-generasi-

millennial/0/sorotan_media

Lesmana, R., \& Hasbiyah, W. (2019). Model Analisis Kepuasan dan Loyalitas Wisatawan Lokal Studi Kasus pada Objek Wisata Kepulauan Seribu Jakarta. JIMF (Jurnal IImiah Manajemen Forkamma), 2(3).

Lesmana, R., Sunardi, N., Hastono, H., \& Widodo, A. S. (2021). Perceived Quality Membentuk Customer Loyalty via Brand Equity pada Pengguna Smartphone Merek Xiaomi di Tangerang Selatan. Jurnal Pemasaran Kompetitif, 4(2), 157-167.

Lesmana, R., \& Ayu, S. D. (2019). Pengaruh Kualitas Produk Dan Citra Merek Terhadap Keputusan Pembelian Kosmetik Wardah PT Paragon Tehnology And Innovation. Jurnal Pemasaran Kompetitif, 2(3), 59-72.

Mariezka, F. I., Hafiar, H., \& Yustikasari, Y. (2018). Pemaknaan Profesi Beauty Vlogger Melalui Pengalaman Komunikasi. Nyimak: Journal of Communication, 2(2), 95. https://doi.org/10.31000/nyimak.v2i2.920

Sunardi, N., \& Lesmana, R. (2020). Konsep Icepower (Wiramadu) sebagai Solusi Wirausaha menuju Desa Sejahtra Mandiri (DMS) pada Masa Pandemi Covid-19. JIMF (Jurnal IImiah Manajemen Forkamma), 4(1).

Sunardi, N., \& Lesmana, R. (2020). Pelaksanaan Alokasi Dana Desa Terhadap Manajemen Keuangan Desa dalam Meningkatkan Efektivitas Program Desa Sejahtera Mandiri Di Desa Cihambulu, Kec. Pabuaran, Kab. Subang. Jurnal SEKURITAS (Saham, Ekonomi, Keuangan dan Investasi), 3(3), 277-288.

Sutarman, A., \& Lesmana, R. (2019). Analisis Keputusan Pembelian Konsumen dari Sisi 
Normtif dan Informatif Pada Supermarket Giant Pamulang, Tangerang Selatan. PROCEEDINGS UNIVERSITAS PAMULANG, 1(1).

Pelayanan, J., Masyarakat, K., Wediawati, T., Aransyah, F., Learning, P. B., Learning, P. B., \& Learning, D. (2019). SOSIALISASI PENGEMBANGAN KEPRIBADIAN GUNA. $1(1), 58-63$.

Prof. Dr. Sugiyono. (2015). Metode Penelitian Kombinasi (Mix Methods). Alfabeta.

Putri, A. W. (2018). PENGGUNAAN INSTAGRAM STORIES SEBAGAI PERSONAL BRANDING (Studi pada Mahasiswa IImu Komunikasi UMM Angkatan 2014) [Universitas Muhammadiyah Malang]. http://eprints.umm.ac.id/id/eprint/43019

Sulistyowati, F., Candra, M. C., \& Dibyorin, R. (n.d.). Partisipasi Warga terhadap Sistem Informasi Desa. 579-588. http://jurnalaspikom.org/index.php/aspikom/article/view/34

Viviana, C., \& Candraningrum, D. A. (2019). E-Wom Oleh Kalangan Milenial Terhadap Akun @makansampaikenyang Sebagai Pemberi Rekomendasi Kuliner. Prologia, 2(2), 270. https://doi.org/10.24912/pr.v2i2.3587 


\section{LAMPIRAN}

Data/foto akun @kekeshabila

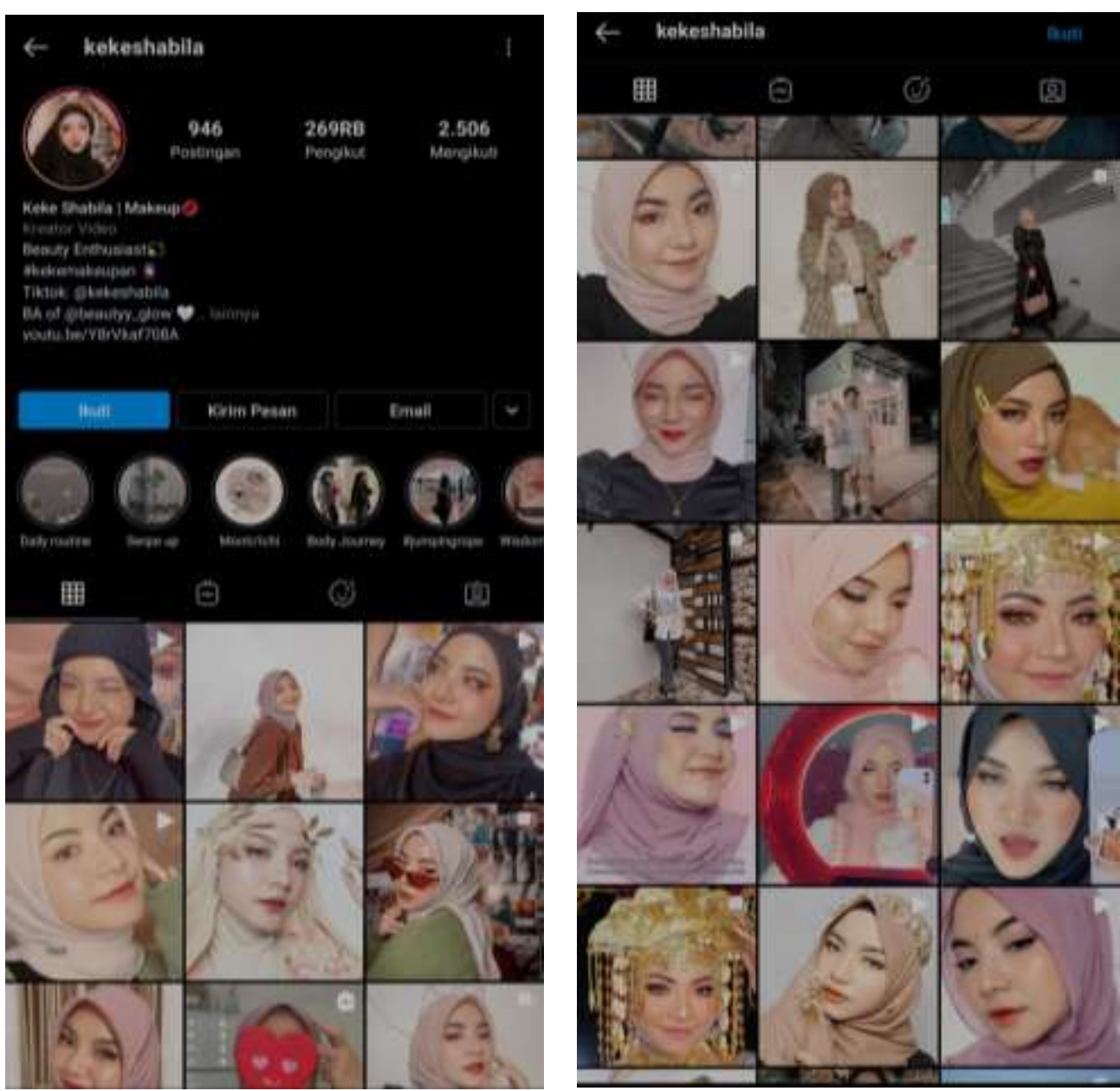


Jurnal Pemasaran

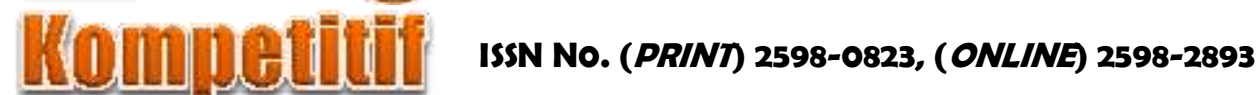

Data/foto akun narasumber
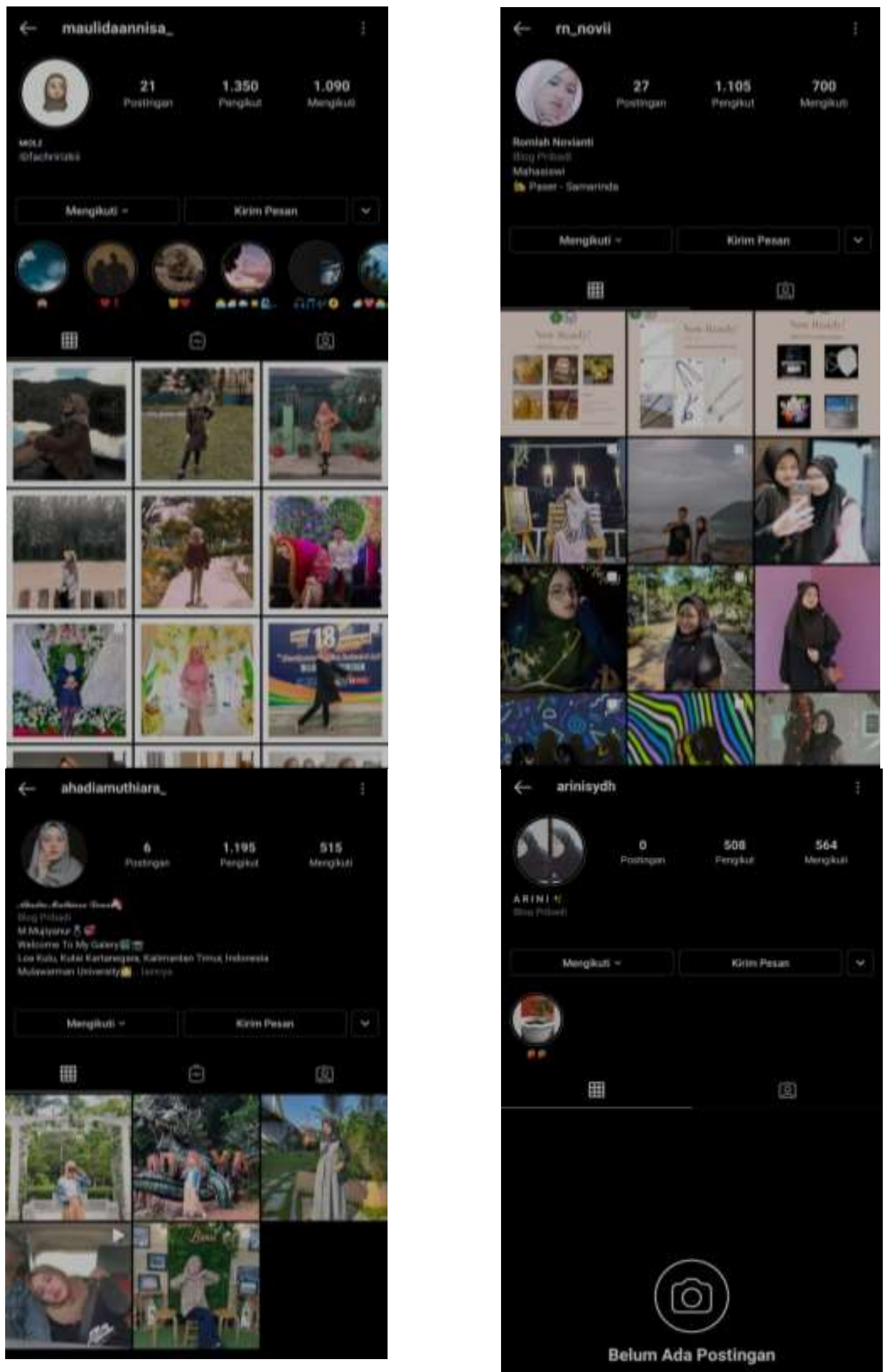

Jurnal Pemasaran Kompetitif, Vol. 04, No. 2 / Februari 2021 
Jurnal Pemasaran

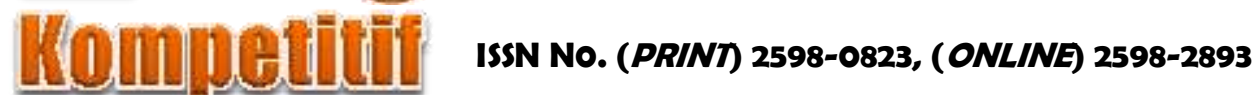

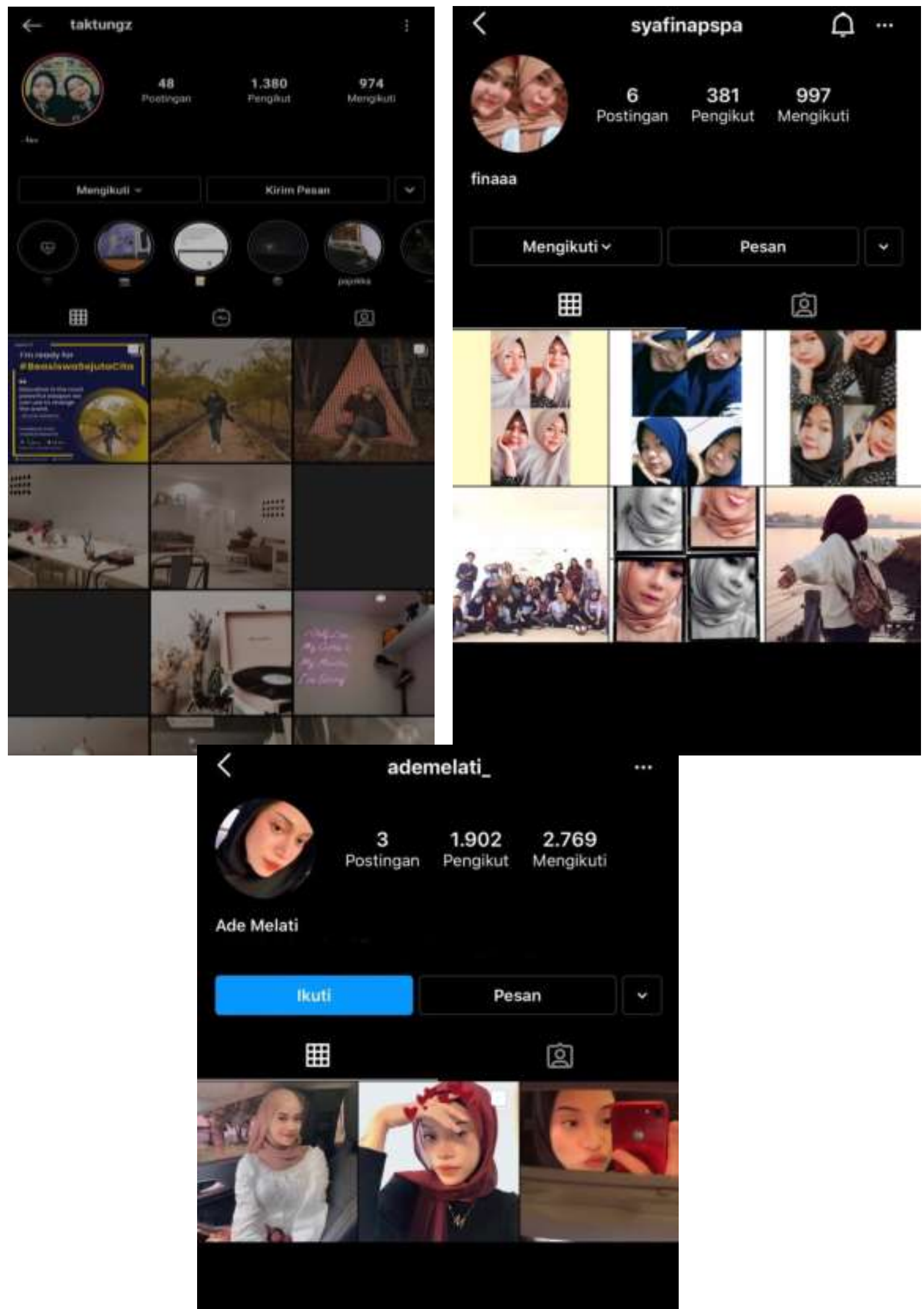

Jurnal Pemasaran Kompetitif, Vol. 04, No. 2 / Februari 2021 
Jurnal Pemasaran

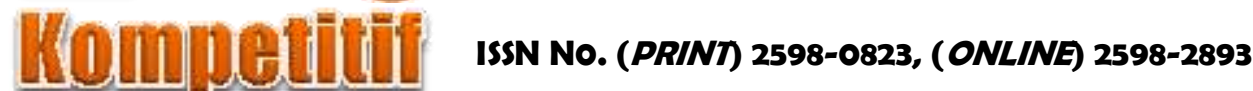

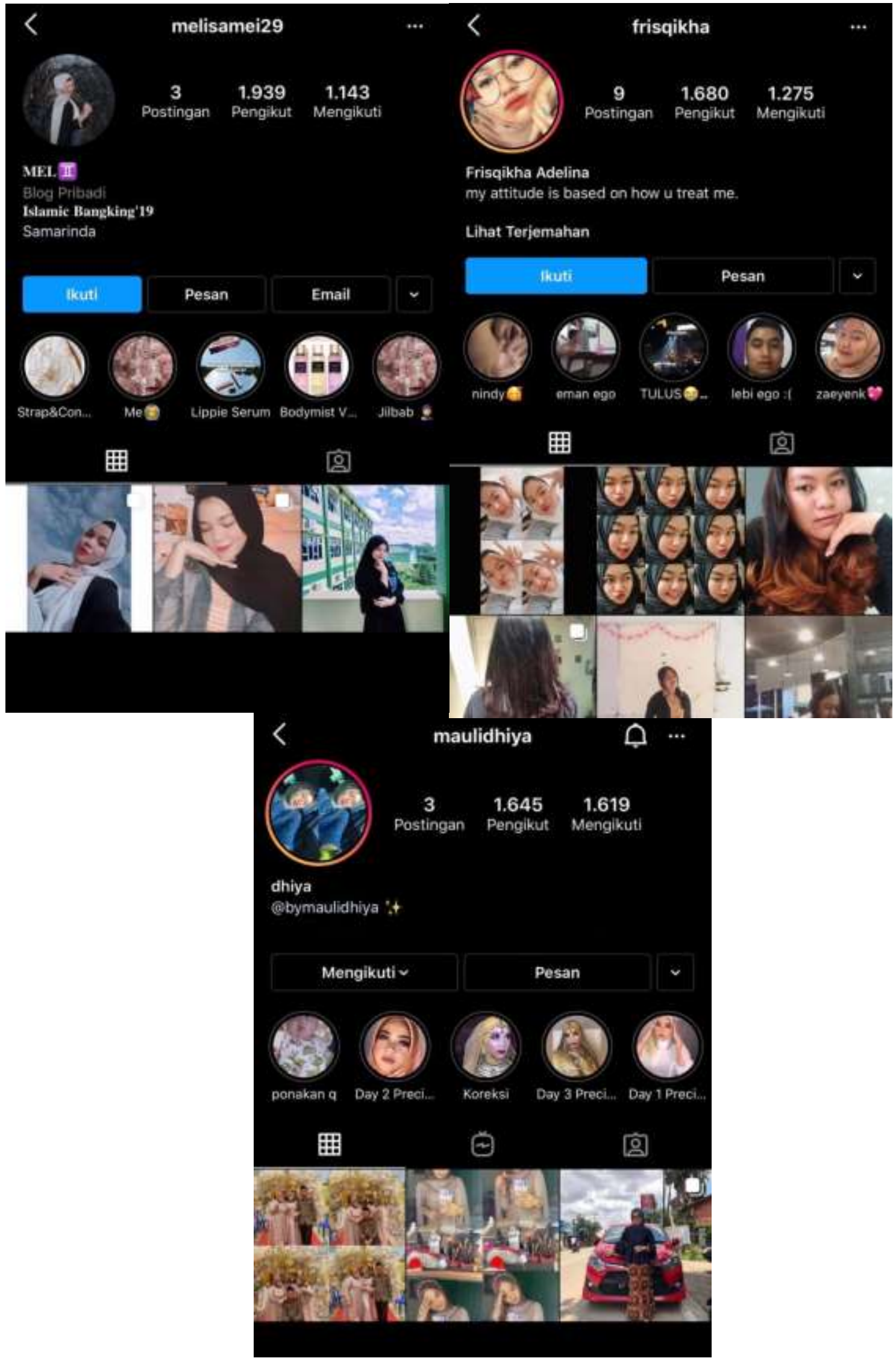

